\title{
POTENSI PARIWISATA MALUKU BARAT DAYA SEBUAH KAJIAN PUSTAKA
}

\author{
Posma Sariguna Johnson Kennedy ${ }^{1}$, \\ Suzanna Josephine L.Tobing ${ }^{2}$, Adolf Bastian Heatubun ${ }^{3}$, dan Rutman Lumbantoruan ${ }^{4}$ \\ ${ }^{1}$ Fakultas Ekonomi dan Bisnis, Universitas Kristen Indonesia, Jakarta, posmahutasoit@gmail.com \\ ${ }^{2,3,4}$ Fakultas Ekonomi dan Bisnis, Universitas Kristen Indonesia, UKI Jakarta 13630
}

\begin{abstract}
ABSTRAK:
Kabupaten Maluku Barat Daya (MBD) adalah salah satu kabupaten yang sangat strategis karena dekat dengan Negara Timor Leste dan Benua Australia. Daya tarik wisata paling dominan di Kabupaten MBD adalah wisata bahari yang terdiri dari pantai dan keindahan alam bawah lautnya. Penulis tertarik untuk mempelajari daerah-daerah yang memiliki potensi wisata di MBD. Penelitian ini dilakukan dengan metode kajian pustaka melalui informasi-informasi sekunder. Luas wilayah laut dan daratan Kabupaten MBD adalah modal untuk pengembangan pariwisata, dimana banyak aset wisata yang sangat potensial untuk dikembangkan.
\end{abstract}

Kata Kunci: Maluku Barat Daya, Potensi Wisata, Wilayah Kepulauan

\section{ABSTRACT:}

Regency of Southwest Maluku is one of the districts in the archipelago region of the State of Indonesia. The area of Southwest Maluku Regency (MBD) is very strategic because it is close to the State of Timor Leste and the Australian Continent. The most dominant tourist attraction in the district of $M B D$ is marine tourism consisting of beaches and natural beauty under the sea. The author is interested in exploring areas that have potential interest in MBD. Research is done by studying the literature by looking for secondary information. The vastness of the territorial sea and tourism of the district of MBD becomes the capital for tourism development. The district of MBD has many potential assets to develop.

Keywords: Southwest Maluku, Tourism Potential, Islands Region

\section{PENDAHULUAN}

Industri pariwisata merupakan salah satu industri terpenting sebagai kontributor Produk Domestik Bruto di suatu negara. Pengembangan sektor pariwisata akan memiliki dampak yang signifikan terhadap industri terkait, seperti hotel, restoran, agen perjalanan dan usaha kecil menengah di daerah kunjungan wisata. Komunitas masyarakat setempat dapat memproduksi dan menjual barang-barang suvenir, sehingga membuka peluang kerja. Industri pariwisata juga mendorong investasi di bidang infrastruktur di daerah kunjungan wisata seperti bandara, jalan, drainase, pengembangan pusat perbelanjaan, dan lain-lain. Kabupaten Maluku Barat Daya (MBD) sangat strategis bila dilihat secara 


\section{National Conference of Creative Industry: \\ Sustainable Tourism Industry for Economic Development}

Universitas Bunda Mulia, Jakarta, 5-6 September 2018 e-ISSN No: 2622-7436

geografis, karena dekat dengan Negara Timor Leste dan Benua Australia. Lokasi strategis ini dapat digunakan sebagai area transit dari dan ke Negara Indonesia. Selain itu juga dapat meningkatkan kunjungan wisata. (Lejar, 2015)

Potensi wisata bahari Indonesia sangat beragam dengan nilai kehidupan lautannya tidak tertandingi di dunia. Indonesiamempunyai berbagai jenis wisata bahari yang tersebar di seluruh nusantara, diantaranya: bisnis pariwisata, wisata tepi pantai, wisata budaya, wisata memancing, wisata pesiar, wisata olahraga, dan banyak jenis wisata bahari lainnya. Akan tetapi, potensi yang dimiliki ini belum sepenuhnya menjadi keunggulan kompetitif bangsa yang dapat berkontribusi besar terhadap perekonomian nasional. Untuk itu, agar pariwisata bahari benar-benar menjadi salah satu pilar ekonomi negara secara berkelanjutan (kawasan/ekositem yang berkelanjutan secara ekonomi), pariwisata maritim harus dibangun dengan strategi yang tepat.(rokhmindahuri.wordpress.com, 2009)

Kabupaten MBD sangat strategis bila dilihat secara geografis, karena dekat dengan Negara Timor Leste dan Benua Australia. Lokasi strategis ini dapat digunakan sebagai area transit dari dan ke Negara Indonesia. Selain itu juga dapat meningkatkan kunjungan wisata. Kabupaten MBD berbeda dengan daerah lain di Indonesia, khususnya di Provinsi Maluku. Daerah ini termasuk daerah tertinggal dan terdiri dari pulau-pulau. Untuk sampai ke sana membutuhkan biaya tidak sedikit dengan transportasi lengkap, baik darat maupun laut. Agak sulit mengembangkan pariwisata dalam waktu singkat untuk wilayah kepulauan. (Lejar, 2015)

Di MBD terdapat beberapa obyek wisata yang dikelola oleh Kantor Kebudayaan dan Pariwisata Daerah. Beberapa contoh kawasan wisata yang potensial untuk dikembangkan adalah pantai Liuketi di Pulau Moa, pantai Kiasar di Pulau Kisar, pantai Metimarang di Pulau Luang, gunung kerbau pulau moa, Danau Tihu di Pulau Wetar, Air Terjun di Regoha di Distrik Mdona Hyera, Pantai Sila di pulau Lakor, Pulau Batu Timur Maupora di Pulau Romang, Gusung Belurerang di Pulau Damer. Selain itu ada juga obyek wisata budaya seperti tari Peuk, tari Seka, wisata sejarah seperti Benteng Volens Haven, Benteng Deles Haven, dan potensi wisata lainnya yang belum tersentuh oleh perkembangannya. Potensi wisata yang telah dikembangkan adalah pantai Liuketi, pantai Kiasar di Kisar, dan beberapa pantai di Babar, dan di Metimarang. Untuk pembangunan, pemerintah kabupaten MBD membangun rumah singgah di 4 (empat) tujuan wisata yaitu Nuwewang Pulau Leti, Pantai Liuketi di Moa, Maupora di Romang dan di Metimarang. Tujuan pemerintah daerah untuk membangun rumah singgah adalah untuk memikat para investor yang datang untuk berinvestasi di wilayah Maluku barat daya. (Letelay, 2016)

\section{TINJAUAN PUSTAKA}

\section{Pariwisata Berkelanjutan ${ }^{1}$}

Pariwisata dalam operasionalnya sangat tergantung terhadap penggunaan dua sumber daya utama, yaitu sumber daya alam dan sumber daya budaya. UU No. 10/2008 tentang Pariwisata mengatakan kawasan wisata adalah kawasan tertentu yang dibangun atau disediakan untuk memenuhi kebutuhan pariwisata. Organisasi pariwisata

\footnotetext{
${ }^{1}$ Naskah Akademik: Strategi Pengembangan Wisata Bahari, 2015.

http://www.kemenpar.go.id/userfiles/2015\%20Strategi\%20Pengembangan\%20Wisata\%20Bahari.pdf
} 


\section{National Conference of Creative Industry: \\ Sustainable Tourism Industry for Economic Development}

Universitas Bunda Mulia, Jakarta, 5-6 September 2018 e-ISSN No: 2622-7436

dunia yang mendefinisikan kawasan tersebut adalah "a physical space in which a visitor spends at least one overnight. It includes tourism products such as support services and attractions, and tourism resources within one day"s return travel time. It has physical and administrative boundaries defining its management and images andperceptions defining its market competitiveness. ”(WTO, 2008)

Sumber Daya Alam (SDA) adalah sesuatu yang ada di sekitar lingkungan alam yang dapat digunakan untuk berbagai kepentingan dan kebutuhan untuk kesejahteraannya. Pada dasarnya SDA dapat dibedakan menjadi dua jenis. Pertama, SDA yang tidak terbarukan (unrenewable) dan SDA yang terbarukan. SDA yang terbarukan adalah SDA yang dapat digunakan berulang-ulang dan dilestarikan, seperti air, keanekaragaman hayati termasuk tanaman, hewan, hasil hutan, dan lain-lain. SDA yang tidak terbarukan adalah SDA yang tidak dapat didaur ulang, hanya digunakan sekali atau tidak dapat dilestarikan, serta dapat punah. Jenis SDA ini sangat terbatas jumlahnya dan umumnya ditemukan di dalam bumi, yang sering disebut penambangan atau penggalian. Dalam kenyataannya, khususnya di pulau-pulau kecil, banyak pihak dalam memanfaatkan sumber daya alam tidak benar-benar menerapkan konsep keberlanjutan. Dalam berbagai kasus, eksploitasi dan eksplorasi sumber daya yang ada menunjukkan bentuk-bentuk kegiatan yang dilakukan adalah merusak dan bukan berorientasi jangka panjang.

Sumber Daya Budaya (SDB) merupakan hasil kerja manusia dalam mempertahankan dan meningkatkan standar kehidupan dan sebagai proses adaptasi terhadap lingkungannya. Sebagai suatu sistem, budaya perlu dilihat dari realisasi kehidupan manusia yang berhubungan dengan ide, perilaku dan material. Budaya manusia pada dasarnya memiliki karakteristik bawaan yang dapat dikelompokkan secara terstruktur, termasuk komponen budaya hidup (sosial, ekonomi, politik, bahasa, agama, estetika dan mata pencaharian); kebijaksanaan dan teknologi (mata pencaharian, kedamaian, kesenangan, bahasa, pengetahuan pendidikan, dan teknologi); serta budaya warisan (artefak, monumen, manuskrip, tradisi dan seni). SDB pada dasarnya mengacu pada beberapa karakteristik masyarakat, mengarah pada bentuk:

a) Pola hidup (peradaban). SDB ini melibatkan lingkungan alam, sosial dan binaan, yang terintegrasi sebagai satu kesatuan pola hidup dan isinya. Hal ini terlihat dalam pola kehidupan masyarakat pesisir, pedalaman (Kubu, Mentawai, Sakai, Dani, Memberamo), atau bentuk-bentuk khusus masyarakat (Bedouin, Naga, Samin, Tengger, Toraja) .

b) Benda budaya (artefak). Bentuk ini diantaranya adalah peninggalan sejarah (bangunan kuno, kompleks bangunan kuno, kota tua, kuil yang belum digunakan untuk ibadah, kereta api, museum dll) yang ada di masyarakat. Termasuk bendabenda yang masih tertentu dalam kompleks kepercayaan (makam suci, kuil, gereja, masjid, kuil, kuil, dll.), Serta kerajinan di toko-toko seni (pasar seni, pusat kerajinan, miniatur bangunan budaya yang kompleks, pasar tradisional, industri tradisional, dan sebagainya)

c) Etnis dan tradisi (adat). Bentuk ini diantaranya adalah budaya masyarakat yang telah menjadi bagian dari institusi seni. Seperti upacara yang berhubungan dengan agama tertentu (pemakaman, penahan, sunat, bahtera, pernikahan, dan lain-lain.); Pementasan (tarian, pantun, rebana, didong, ketimping tamborin, sambra, drama, dan lain-lain); serta berbagai permainan anak.

Dalam perumusan UNESCO, warisan budaya adalah warisan yang tak berwujud, 


\section{National Conference of Creative Industry: \\ Sustainable Tourism Industry for Economic Development}

Universitas Bunda Mulia, Jakarta, 5-6 September 2018 e-ISSN No: 2622-7436

seperti tradisi lisan, bahasa, proses penciptaan kemampuan dan pengetahuan, seni pertunjukan, festival agama dan keyakinan, kosmologi, sistem pembelajaran dan keyakinan dan praktik kepercayaan yang terkait dengan alam. Kekayaaan budaya ini perlu diikuti oleh pengembangan manajemen aset budaya alam. Berbagai bentuk aset berharga ini merupakan modal budaya yang perlu dikelola sesuai dengan kondisi masing-masing. Salah satu langkah untuk menerapkan kebijakan pengembangan pariwisata berkelanjutan, yaitu program pengembangan produk pariwisata diprioritaskan pada konsep pengembangan ekowisata dan pariwisata budaya.Harapannya dapat berperan dalam upaya pemerintah dalam meningkatkan kesejahteraan masyarakat. Selain itu, dapat berperan dalam upaya pelestarian lingkungan dan meningkatkan apresiasi publik terhadap warisan budaya yang mereka miliki. Pariwisata yang tepat adalah pariwisata yang secara aktif membantu dalam menjaga keberlanjutan suatu wilayah budaya, sejarah dan alam.

\section{METODE PENELITIAN}

Berdasarkan paparan di atas, penulis tertarik untuk mengeksplorasi daerah-daerah yang memiliki potensi wisata di Kabupaten Maluku Barat Daya. Penelitian ini merupakan penelitian kualitatif dilakukan dengan metode kajian pustaka melalui pencarian informasi sekunder dari berbagai situs web yang ditelusuri melalui internet.

\section{HASIL PENELITIAN DAN PEMBAHASAN}

Profil Kabupaten Maluku Barat Daya (MBD)

Kabupaten MBD merupakan kabupaten di Provinsi Maluku, yang terletak pada koordinat antara 6-10 Lintang Selatan dan 12540 '- 130 30', dengan luas wilayah 8.648 $\mathrm{km}^{2}$, dengan Ibu Kota Tiakur, Moa Lakor. Kabupaten ini dibentuk berdasarkan UU No. 31/2008 yang merupakan pemekaran dari Kabupaten Maluku Tenggara (P. R. Indonesia, 2008) Wilayah Kabupaten Maluku Barat Daya berbatasan di utara dengan Kabupaten Maluku Tengah dan Laut Banda, di selatan berbatasan dengan Laut Timor dan Selat Wetar, di barat dengan Kabupaten Alor, dan di timur dengan Kabupaten Maluku Tenggara Barat.(Wikipedia, 2018)

Luas wilayah MBD adalah 72.427,2 km, dengan wilayah laut mencakup 63.773,20 $\mathrm{km}(88 \%)$ dan wilayah daratnya sebesar 8.648,01 km (11\%).Keseluruhan Kabupaten MBD terdiri dari tiga gugusan kepulauan, yaitu Gugus Kepulauan Terselatan, Gugus Lemola, dan Gugus Kepulauan Babar. MBD merupakan salah satu kawasan prioritas konservasi dan pengelolaan perikanan berkelanjutan di Indonesia, karena berada di Bentang Laut Sunda Banda. Kawasan ini seluas 151 juta hektar merupakan bagian dari Segitiga Terumbu Karang yang memiliki keanekaragaman hayati laut yang terting gi di dunia. (Estradivari, eta.ll, 2015) 


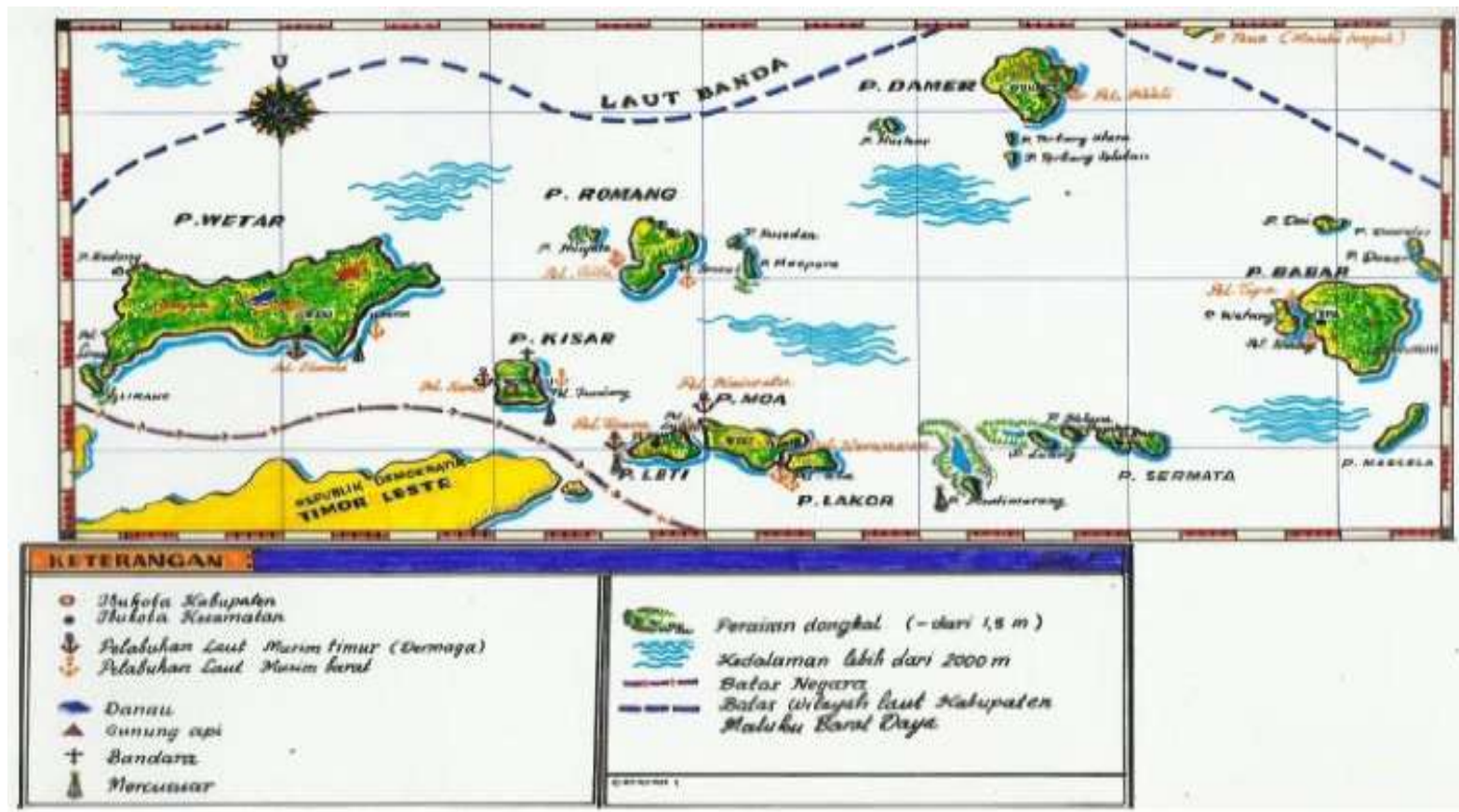

Gambar 1. Kabupaten Maluku Barat Daya (Lejar, 2015)

Secara administratif, Kabupaten Maluku Barat Daya dibagi menjadi 8 (delapan) kecamatan, termasuk di dalamnya Kabupaten Babar Timur, Kepulauan Babar, Mdona Hiera, Leti, Moa lakor, Pulau Terselatan, Wetar, Damer. Kemudian terdiri dari 117 desa utama, 8 anak desa yang masih berkembang, termasuk 21 desa swadaya, 62 desa swadaya dan 34 desa swasembada. (Lejar, 2015)

Tabel 1. Wilayah Kepulauan Berdasarkan Kecamatan

\begin{tabular}{|l|l|l|}
\hline No & Kecamatan & Nama Pulau \\
\hline 1 & Kecamatan Babar Timur & Pulau Babar, Pulau Daweloor, Pulau Dawera \\
\hline 2 & Kecamatan Damer & $\begin{array}{l}\text { Pulau Damar, Pulau Nursieur, Pulau Terbang Selatan, Pulau } \\
\text { Terbang Utara }\end{array}$ \\
\hline 3 & Kecamatan Leti & Pulau Leti \\
\hline 4 & Kecamatan Mdona Hiera & $\begin{array}{l}\text { Pulau Amartaun, Pulau Dona, Pulau Kalapu, Pulau Laikro, Pulau } \\
\text { Laitunan, Pulau Luang, Pulau Meaterialam, Pulau Meatimiarang, } \\
\text { Pulau Meitutun, Pulau Mora, Pulau Sermata, Pulau Tiata, Pulau } \\
\text { Warwawang }\end{array}$ \\
\hline 6 & Kecamatan Moa Lakor & Pulau Lakor, Pulau Moa \\
\hline 7 & Kecamatan P.P Wetar & $\begin{array}{l}\text { Pulau Juha, Pulau Kisar, Pulau Laut, Pulau Limtutu, Pulau } \\
\text { Maopora, Pulau Mitan, Pulau Nyata, Pulau Romang, Pulau Teliang }\end{array}$ \\
\hline 8 & Kecamatan P.P Babar & Pulau Lirang, Pulau Reong, Pulau Wetar \\
\hline
\end{tabular}

Sumber: RPJMD Kabupaten Maluku Barat Daya, 2011 (Lejar, 2015)

Kabupaten MBD memiliki laju pertumbuhan penduduk sebesar 0,87\%(BPS Kabupaten Maluku Barat Daya dalam Angka, 2014). Walaupun sarana dan prasarana pendidikan masih relatif minim dan tidak merata, namun sebagian besar penduduknya merupakan lulusan sekolah menengah. Bahkan tidak sedikit yang menempuh jenjang perguruan tinggi. Sebagian besar mata pencaharian utama masyarakat adalah berkebun. Mereka umumnya menjual hasil kebun ke desa atau pulau tetangga, baik dengan sistem pembayaran atau barter. Kecuali di Pulau Luang dimana seluruh masyarakatnya adalah 


\section{National Conference of Creative Industry: \\ Sustainable Tourism Industry for Economic Development}

Universitas Bunda Mulia, Jakarta, 5-6 September 2018 e-ISSN No: 2622-7436

nelayan dan pembudidaya rumput laut, kegiatan perikanan atau menangkap ikan di Kabupaten MBD umumnya dilakukan hanya untuk memenuhi kebutuhan protein harian. Meski bukan sebagai mata pencaharian utama, perikanan menjadi bagian penting dari kehidupan harian dan budaya masyarakat MBD.(Estradivari, et.all, 2015)

Penduduk Maluku Barat Daya mempunyai mata pencaharian utama bercocok tanam dan beternak. Penduduk sangat tergantung pada kondisi iklim, dua musim dalam setahun. Masa bercocok tanampada umumnya dilakukan pada peralihan musim timur ke barat untuk tanaman pangan utama jagung dan ubi. Jagung dan ubi merupakan makanan utama penduduk MBD, sedangkan di Pulau Damar saguadalah makanan utama. Pertanian yang ada masih dilakukan secara tradisional.Tanaman untuk makanan selain jagung, banyak kacang-kacangan, lapatulokal, kacang atau kacang kayu merah dan singkong (ubi jalar). Tanaman ekonomis daerah seperti kelapa (untuk produksi kopra) dan jeruk manis merupakan sumberpendapatan selain dari memelihara kambing, domba dan babi, serta membuat tuak/ sopi. Pulau Kisar sudahlama dikenal dengan jeruk Kisar dan kambing Kisar selain Sopi Kisar produksi Rumahan..Laut memberikan kontribusi, perikanan merupakan salah satu kegiatan masyarakat. terutama untuk warga yang tinggal di dekat pantai. Penangkapan ikan terikat pada musim. Misalnya,selama musim timur, sebuah desa di sisi timur pulau banyak banyak menangkap ikan karena merupakan musim panas, kegiatan bercocok tanam akan terhenti.(Caesar, 2009)

Tradisi dan adat istiadat, terutama terkait adat pernikahan dan pemerintahan desa, masih cukup kental di kalangan masyarakat MBD. Di sebagian besar desa, fungsi kepala desa juga mencakup fungsi dari raja, dan di beberapa desa. Hanya masyarakat dari marga raja yang bisa mencalonkan diri menjadi kepala desa. Masyarakat MBD juga mempunyai modal sosial yang tinggi terkait ketertiban bermasyarakat dan desa dengan berbagai peraturan desa yang mengatur tata hubungan bermasyarakat. Sanksi hukuman yang cukup berat, baik secara adat maupun ekonomi, juga masih ditegakkan dengan baik oleh perangkat desa. Sistem kepemilikan tanah di sebagian besar wilayah MBD masih belum bersertifikat hak milik dan merupakan tanah adat. Konflik sosial, sebagian besar terjadi biasanya terkait dengan permasalahan pemanfaatan lahan. Konflik sosial ini seringkali diselesaikan secara kekeluargaan dengan mediasi tokoh adat. (Estradivari, et.all, 2015)

\section{Potensi Pariwisata Kabupaten Maluku Barat Daya}

Daya tarik wisata yang paling dominan di Kabupaten MBD adalah wisata bahari yang terdiri dari pantai dan keindahan alam bawah air. Selain itu, daya tarik wisata budaya dan sejarah juga dimiliki oleh Kabupaten MBD. Secara lebih jelas daya tarik wisata yang ada di Kabupaten Maluku Barat Daya sebagai berikut:

Tabel 2. Tujuan Wisata Potensial Maluku Barat Daya 
National Conference of Creative Industry: Sustainable Tourism Industry for Economic Development

Universitas Bunda Mulia, Jakarta, 5-6 September 2018 e-ISSN No: 2622-7436

\begin{tabular}{|l|l|l|}
\hline \multicolumn{1}{|c|}{ Destinasi Pariswisata } & \multicolumn{1}{c|}{ Gambar Destinasi } \\
\hline 1. & Pantai Nama & \\
\hline & $\begin{array}{l}\text { Letak: sebelah barat Pulau Kisar. } \\
\text { Merupakan pelabuhan utama Wonreli, berjarak 1 } \\
\text { Jalan setapak menuju pantai belum memadai, } \\
\text { jika mengunakan kendaraan bermotor sering } \\
\text { terjadi ban slip karena merupakan pasir gembur. }\end{array}$ & \\
\hline
\end{tabular}




\section{National Conference of Creative Industry: Sustainable Tourism Industry for Economic Development}

Universitas Bunda Mulia, Jakarta, 5-6 September 2018 e-ISSN No: 2622-7436

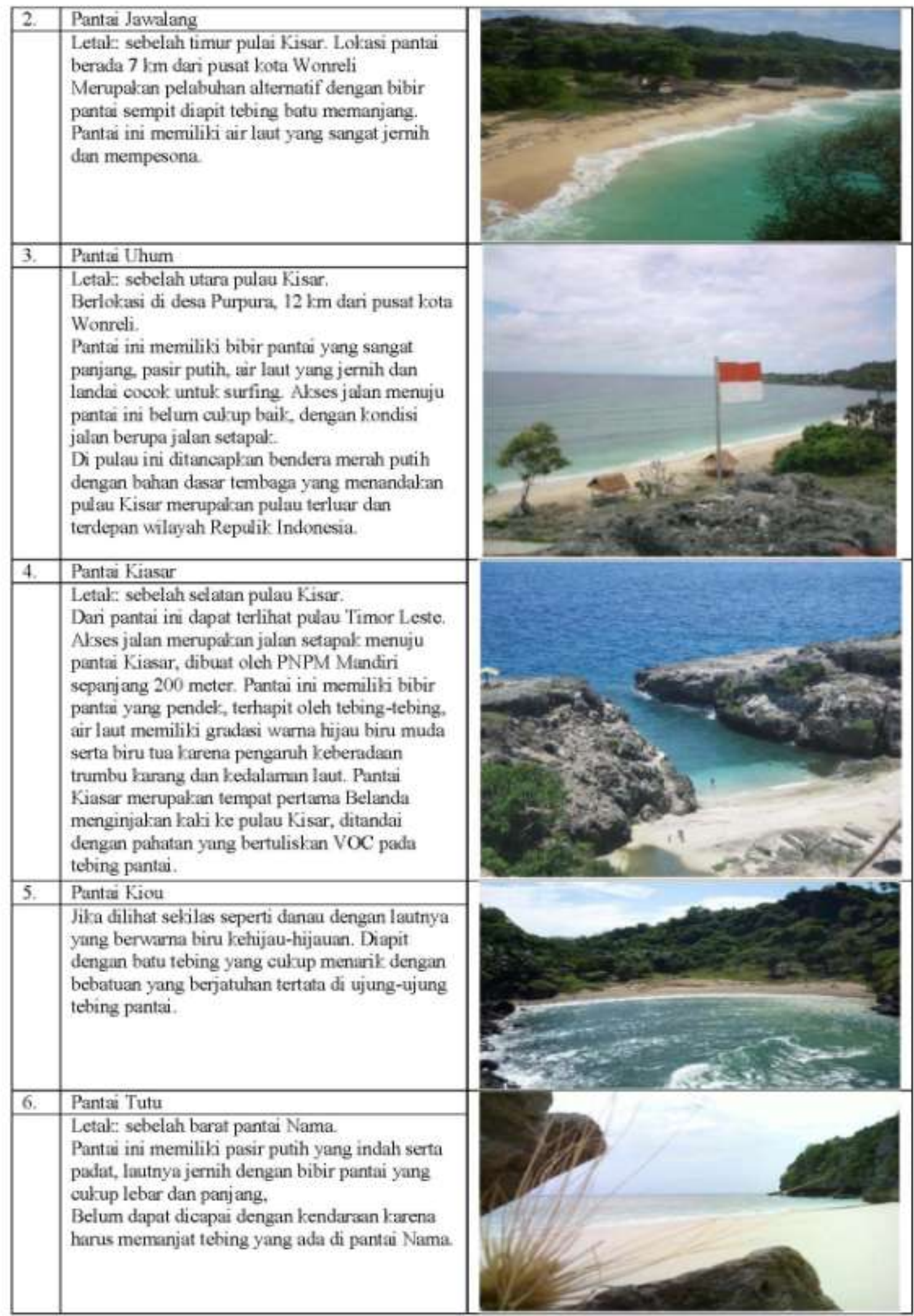


National Conference of Creative Industry: Sustainable Tourism Industry for Economic Development Universitas Bunda Mulia, Jakarta, 5-6 September 2018 e-ISSN No: 2622-7436

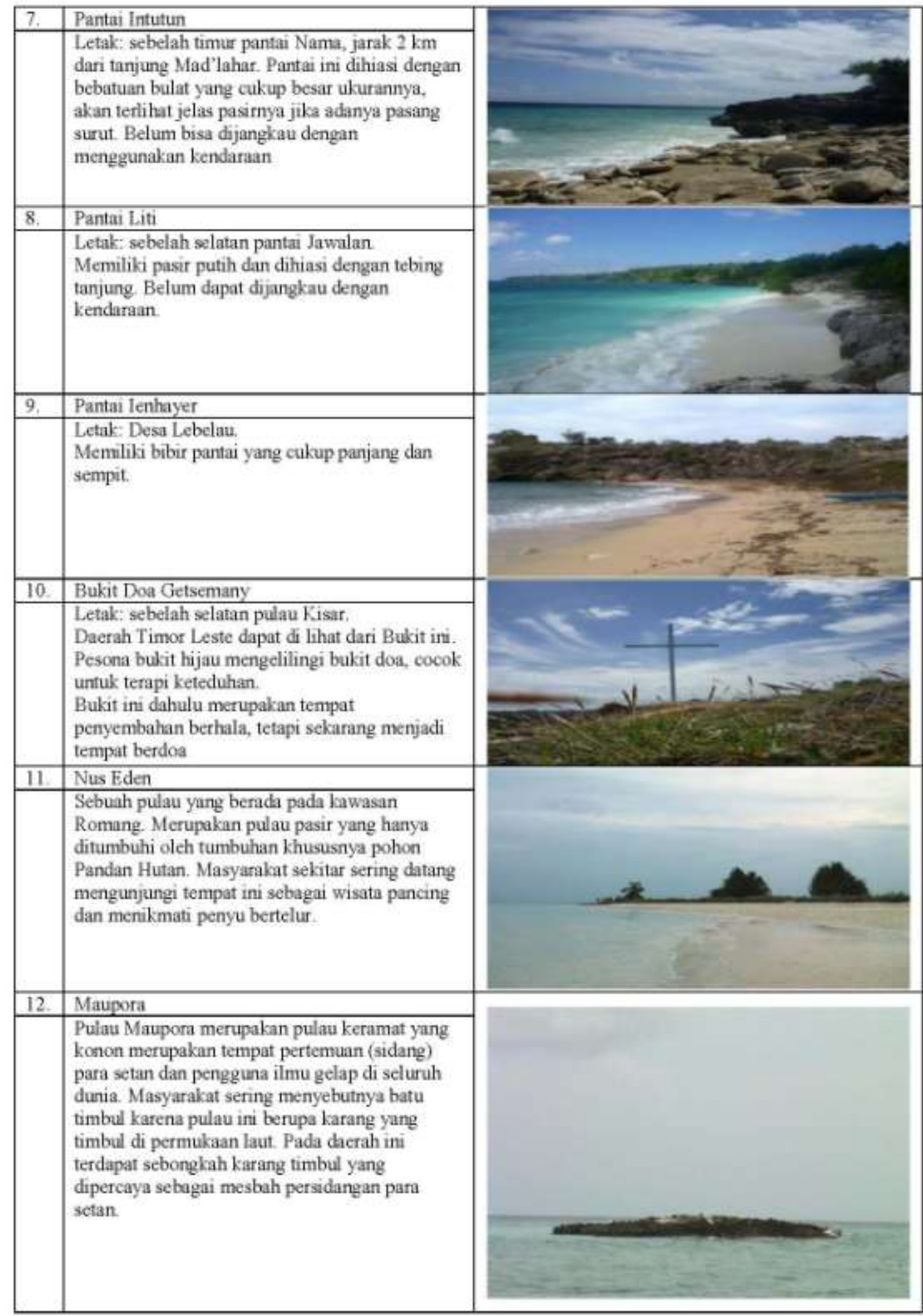




\section{National Conference of Creative Industry: Sustainable Tourism Industry for Economic Development}

Universitas Bunda Mulia, Jakarta, 5-6 September 2018 e-ISSN No: 2622-7436

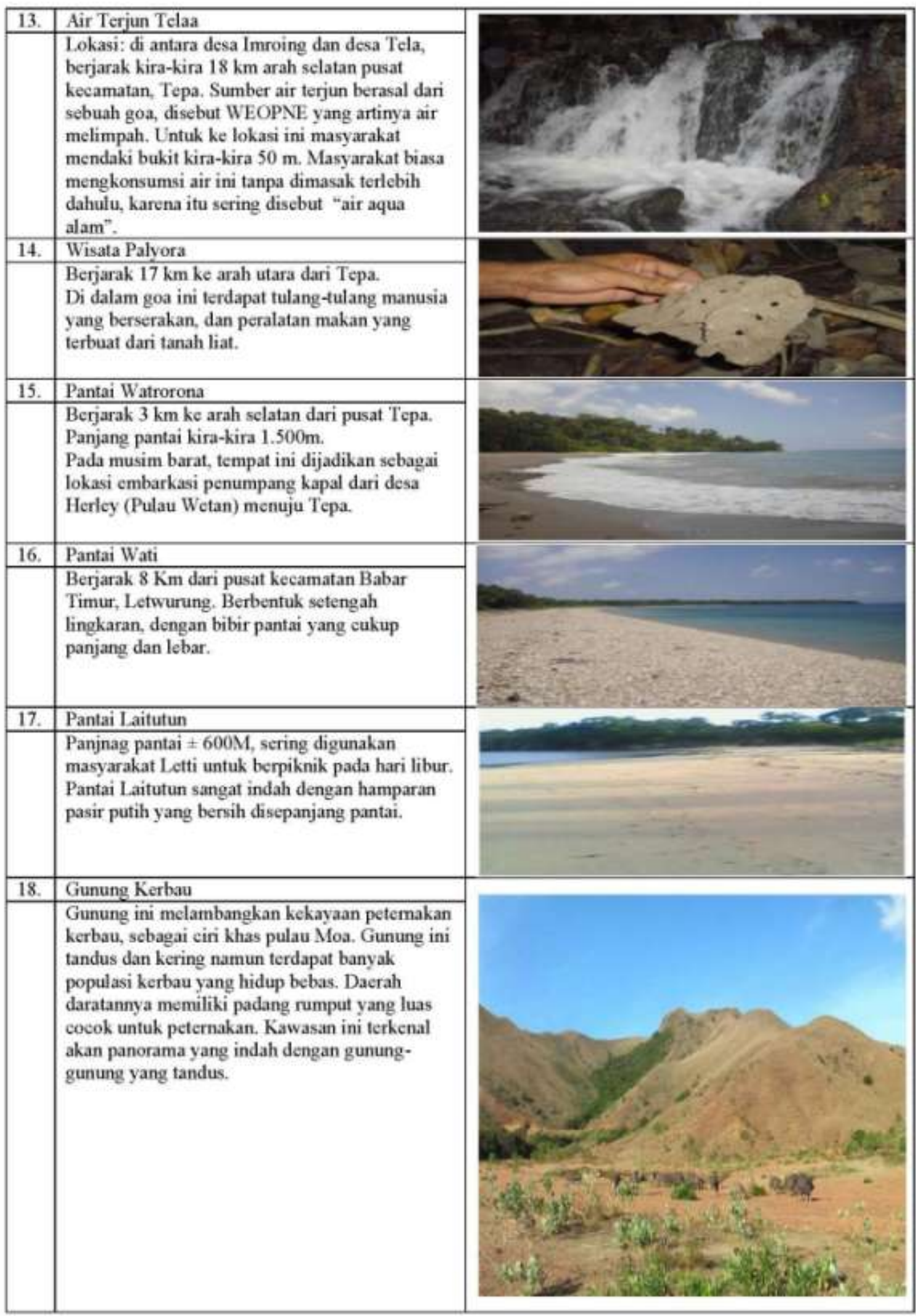




\section{National Conference of Creative Industry: Sustainable Tourism Industry for Economic Development}

Universitas Bunda Mulia, Jakarta, 5-6 September 2018 e-ISSN No: 2622-7436

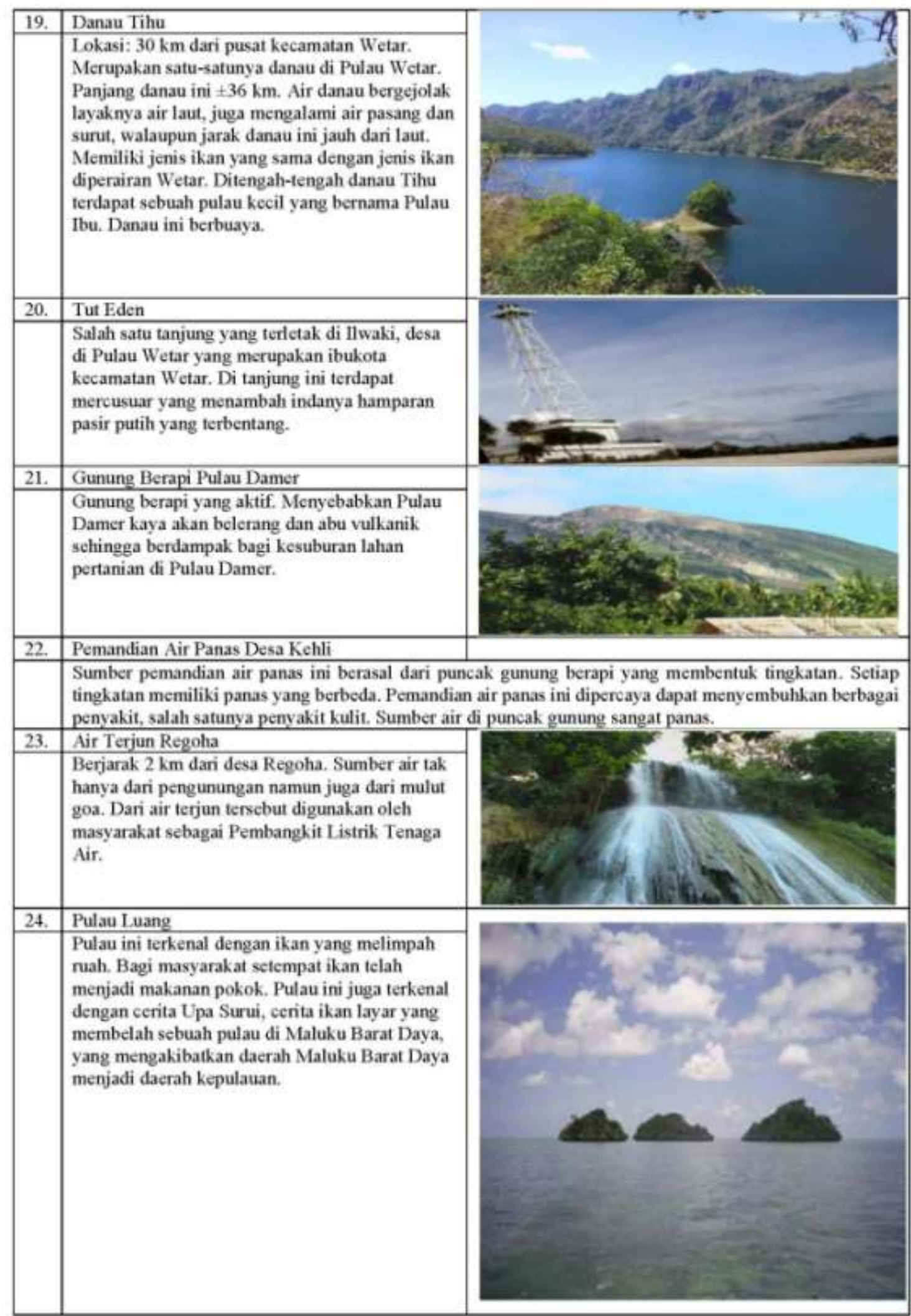




\section{National Conference of Creative Industry: Sustainable Tourism Industry for Economic Development}

Universitas Bunda Mulia, Jakarta, 5-6 September 2018 e-ISSN No: 2622-7436

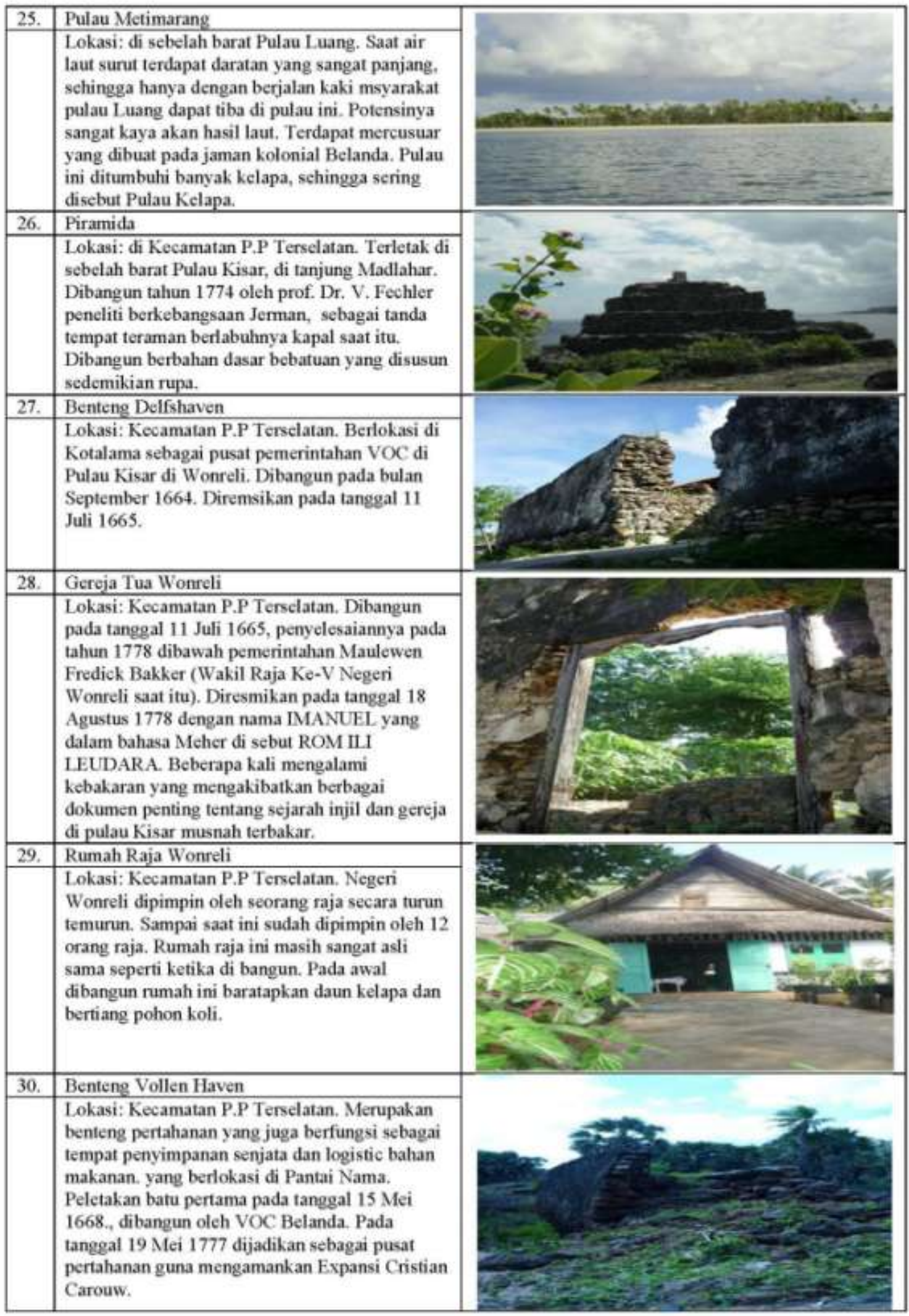


National Conference of Creative Industry: Sustainable Tourism Industry for Economic Development Universitas Bunda Mulia, Jakarta, 5-6 September 2018 e-ISSN No: 2622-7436

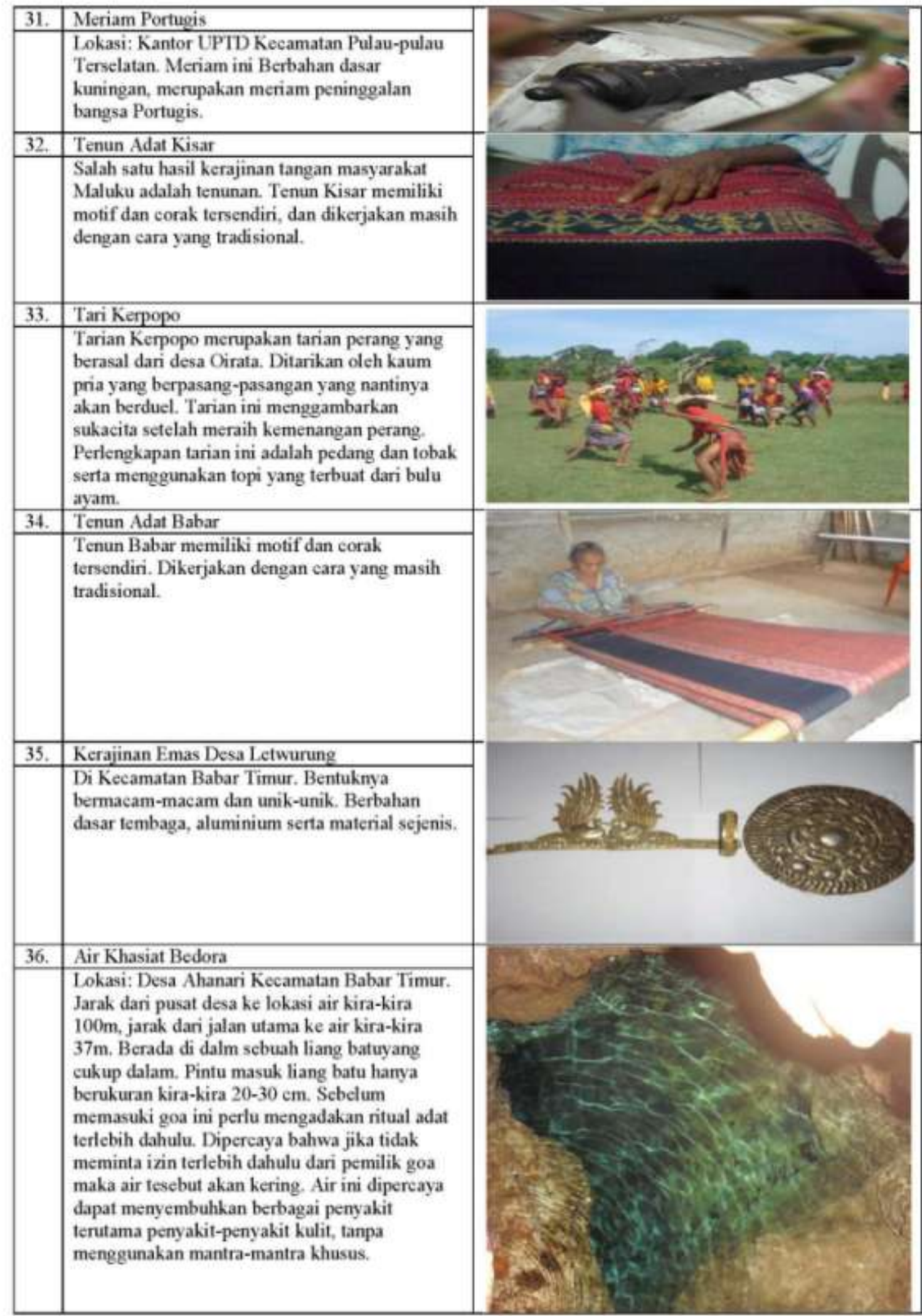




\section{National Conference of Creative Industry: Sustainable Tourism Industry for Economic Development}

Universitas Bunda Mulia, Jakarta, 5-6 September 2018 e-ISSN No: 2622-7436

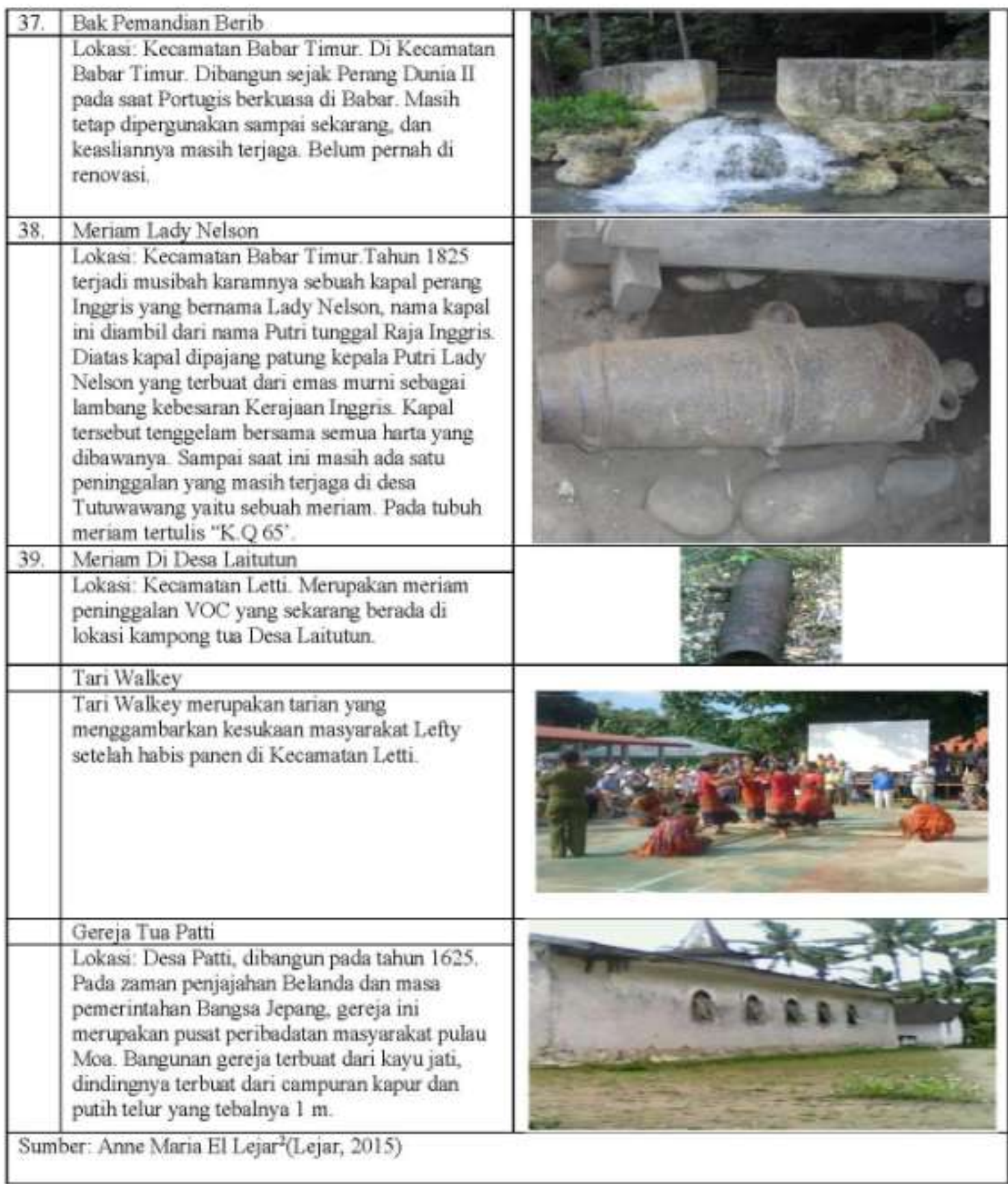

\section{Sumber Daya Manusia}

Luas luas laut dan daratan Kabupaten MBD merupakan modal untuk pengembangan pariwisata, dengan banyaknya aset wisata yang sangat potensial untuk dikembangkan. Namun, sumber daya alam yang dimiliki bukan hanya faktor penentu, tetapi juga membutuhkan kemampuan sumber daya manusia untuk merencanakan, mengelola dan juga memasarkan pariwisata mereka. Kabupaten MBDmerupakan kabupaten yang belum berdiri lama, sehingga kekurangan sumber daya manusia yang dapat mengelola aset pariwisata sebagai sumber penghasilan. Kurangnya sumber daya manusia di sektor pariwisata mempengaruhi perkembangan dan daya tarik wisata MBD, terutama dalam hal mengelola aset pariwisata daerah. Potensi wisata akan memberikan 


\section{National Conference of Creative Industry: \\ Sustainable Tourism Industry for Economic Development}

Universitas Bunda Mulia, Jakarta, 5-6 September 2018

e-ISSN No: 2622-7436

hasil yang sangat produktif jika direncanakan dan dikembangkan secara terencana dan terintegrasi dengan perencanaan pembangunan daerah. Kurangnya sumber daya manusia juga mempengaruhi ide dan gagasan untuk mengembangkan pariwisata secara holistik, termasuk menyiapkan sarana dan prasarana yang akan memiliki nilai strategis dalam pengembangan pariwisata di Kabupaten MBD.

Secara umum, masyarakat di Kabupaten MBD ramah dan terbuka bagi para migran. Dalam perkembangan pariwisata, kondisi masyarakat seperti ini adalah kekuatan. Dengan keramahan dan keterbukaan dapat meminimalkan konflik antara masyarakat dan wisatawan. Selain itu, sebagian orang berharap pengembangan pariwisata akan dapat meningkatkan kesejahteraan dan membuka isolasi kawasan di Kabupaten MBD. Berbagai kegiatan/acara telah digelar, seperti kapal pesiar Orion dari Australia, Sail Banda, dan berbagai pertunjukan kesenian. Namun acara-acara tersebut masih belum dapat meningkatkan jumlah kunjungan wisatawan secara signifikan. Kegiatan ini merupakan daya tarik bagi Kabupaten MBD, sehingga dapat digunakan sebagai acara yang rutin dilakukan setiap tahun. Salah satu kunjungan kapal pesiar yang sering mengunjungi pulau MBD adalah kapal pesiar Orion dari Australia. Para wisatawan ini menamai kepulauan MBD sebagai The Lost Island, karena mereka melihat banyak keindahan baik dalam sifat budaya dan sejarah yang tidak diketahui banyak orang, karena lokasinya di sisi luar bagian selatan Indonesia.(Lejar, 2015)

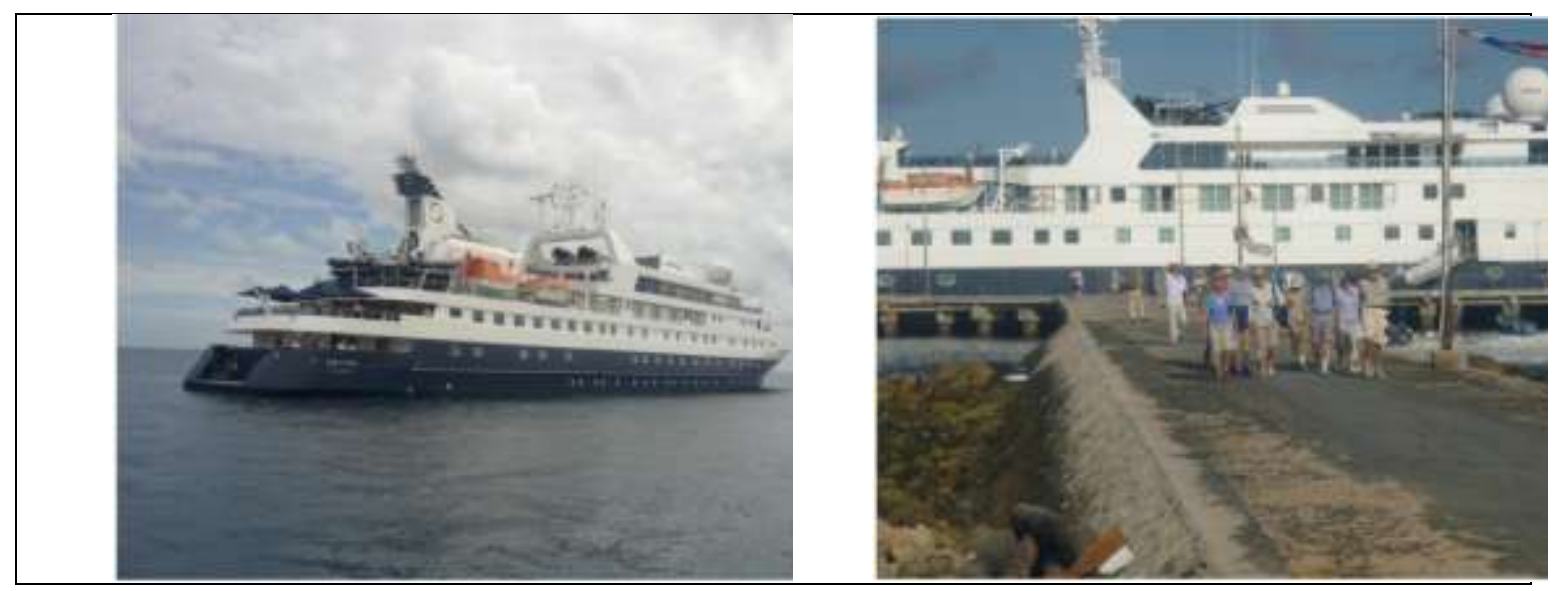

Gambar 2. Orion Yacht - Australia (Lejar, 2015)

\section{KESIMPULAN}

Pariwisatadi Kabupaten Maluku Barat Daya (MBD) memiliki potensi yang dapat dikembangkan, karena memiliki sumber daya yang kaya, baik alam dan budayanya. Kondisi fisik kawasan, sejarah dan masyarakat Kabupaten MBD juga berpotensi dimanfaatkan secara optimal untuk kepariwisataan secara berkelanjutan. Namun Kabupaten MBD kurang memiliki sumber daya manusia yang mampu mengembangkan potensi-potensi wisata ini.Termasuk perlunya menyiapkan sarana dan prasarana yang memiliki nilai strategis pada pengembangan pariwisata. 


\section{DAFTAR PUSTAKA}

Caesar4u.blogspot. (2009). Maluku Barat Daya. In mauteri.nl. Retrieved from http://mbd-caesar4u.blogspot.co.id/2009/04/gambaran-umum-wilayah-malukubarat-daya.html.

Dahuri, 2019. https://rokhmindahuri.wordpress.com/2009/02/02/strate gipengembangan-pariwisata-bahari/

Estradivari, Nara Wisesa, Adrian Damora, Christian Handayani1, Amkieltiela, Berbudi Wibowo, Ignatius Tri Hargiyatno, dan H. M. H. (2015). MENGUAK POTENSI EKOLOGI , SOSIAL , DAN PERIKANAN MALUKU BARAT DAYA: SEBUAH TEMUAN AWAL. WWF-Indonesia. Jakarta. Retrieved from www.wwf.or.id/xpdembd

Indonesia, K. K. dan P. R. Kepmen Kelautan dan Perikanan RI Nomor 51 tahun 2016 tentang Penetapan Lokasi Pembangunan SKPT, Pub. L. No. 27 September 2016 (2016). Indonesia: KKP Biro Hukum dan Organisasi.

Indonesia, P. R. UU RI No.31/2008 TENTANG PEMBENTUKAN KABUPATEN MALUKU BARAT DAYA DI PROVINSI MALUKU

Kemenpar, 2015, Naskah Akademik: Strategi Pengembangan Wisata Bahari, http://www.kemenpar.go.id/userfiles/2015\%20Strategi\%20Pengembangan\%20W isata\%20Bahari.pdf

Lejar, A. M. El. (2015). El Lejaro Travel Hunt Kepulauan Maluku Barat Daya “ The Lost Islands of Indonesia ." Maluku Barat Daya. Retrieved from https://ellejartravelhunt.wordpress.com/2015/05/22/93/

Letelay, M. Y. (2016). POTENTIAL TOURISM IN MALUKU. Retrieved from https://malukubaratdayablog.wordpress.com/2016/06/02/potential-tourism-inmaluku-barat-daya/

Tribun-Maluku.com. (2016, April). Pulau Moa Akan Dijadikan Sentra Pengembangan Perikanan Terpadu. Tibun_Maluku.com. Retrieved from http://www.tribunmaluku.com/2016/04/pulau-moa-akan-dijadikan-sentra-pengembanganperikanan-terpadu.html

Wikipedia. (2018). KABUPATEN MALUKU BARAT DAYA. In Wikipedia bahasa Indonesia, ensiklopedia bebas. Wikipedia. Retrieved from https://id.wikipedia.org/wiki/Kabupaten_Maluku_Barat_Daya 